\title{
First thyreophoran dinosaur from the Middle Jurassic (Bajocian) of Luxembourg
}

\author{
Dominique DELSATE ${ }^{*}$, Xabier PEREDA-SUBERBIOLA ${ }^{2}$, Roland FELTEN ${ }^{1}$ \& Gilles FELTEN ${ }^{1}$ \\ ${ }^{1}$ Musée national d'Histoire naturelle de Luxembourg, Centre de Recherche Scientifique, 25 Rue Münster, L-2160 Luxembourg; \\ dominique.delsate@mnhn.lu. \\ ${ }^{2}$ Universidad del País VascolEuskal Herriko Unibertsitatea (UPVIEHU), Facultad de Ciencia y Tecnología, Departamento de \\ Estratigrafia y Paleontología, Apartado 644,48080 Bilbao, Spain; xabier.pereda@ehu.eus. \\ * corresponding author
}

\begin{abstract}
An isolated dinosaur osteoderm from the Rumelange-Ottange (Cimalux, formerly Intermoselle) Quarry of the Grand Duchy of Luxembourg is described. The fossil was found in marly-calcareous deposits of the "Marnes sableuses d'Audunle-Tiche", which are Middle Jurassic in age (Humphriesianum Zone, Lower Bajocian). The deposits correspond to an open sea environment with an abundant and diverse marine fauna, including invertebrates, actinopterygians, hybodonts, neoselachians, plough-nose chimaeras, and marine reptiles. The oval, low-keeled osteoderm has a roof-like appearance and is here identified as a thyreophoran dermal scute. It could belong to a basal thyreophoran or, more tentatively, to an early ankylosaur. The specimen was probably a remnant of a floating carcass that drifted over a distance from a land area. The dermal scute from the OttangeRumelange Quarry represents the second Jurassic dinosaur reported to date from Luxembourg, and the first one described from the Bajocian. Moreover, it is one of the few non-stegosaurian thyreophoran records of Middle Jurassic age.
\end{abstract}

KEYWORDS: Dinosauria, Thyreophora, osteoderm, Middle Jurassic, Bajocian, Grand Duchy of Luxembourg.

RÉSUMÉ. Le premier Dinosaure thyréophore du Jurassique moyen (Bajocien) du Grand-Duché de Luxembourg. Un ostéoderme isolé de dinosaure provenant de la carrière d'Ottange-Rumelange (Cimalux, auparavant Intermoselle) du Grand-Duché de Luxembourg est ici décrit. Le fossile a été trouvé dans des dépôts marno-calcaires des "Marnes sableuses d'Audun-le-Tiche", d'âge Jurassique moyen (Zone Humphriesianum, Bajocien inférieur). Les dépôts correspondent à un environnement marin ouvert qui a fourni une faune abondante et variée, comprenant invertébrés, actinoptérygiens, hybodontes, néosélaciens, chimères et reptiles marins. L'ostéoderme, ovale et portant une quille basse, en forme de toit, est identifié comme étant un écusson dermique d'un thyréophore. Il pourrait appartenir à un thyréophore basal ou, plus provisoirement, à un des premiers ankylosaures. Le spécimen provient probablement d'une carcasse flottante qui a dérivé sur une certaine distance depuis la terre ferme. L'écusson dermique de la carrière d'Ottange-Rumelange représente le deuxième dinosaure décrit jusqu'à présent au Luxembourg et le premier trouvé dans le Bajocien. D'autre part, il s'agit d'une des rares découvertes de dinosaures thyréophores non-stégosauriens dans le Jurassique moyen.

MOTS-CLÉS: Dinosauria, Thyreophora, ostéoderme, Jurassique moyen, Bajocien, Grand-Duché de Luxembourg.

\section{Introduction}

Thyreophora is a clade of herbivorous ornithischian dinosaurs that are mainly characterized by the presence of lateral rows of keeled osteoderms (or dermal bones) on the dorsum of the body (Sereno 1999; Butler et al., 2008). Thyreophora is defined as all taxa more closely related to Ankylosaurus than to Triceratops (Sereno, 1998). Thyreophorans comprise ankylosaurs, stegosaurs, and several more basal taxa such as Scutellosaurus, Emausaurus and Scelidosaurus (Norman et al., 2004). The dermal armour is extensively developed in ankylosaurs, with an osseous cranial ornamentation and multiple parasagittal rows of dermal elements (i.e., scutes, plates, spines, ossicles, tubercles) on the dorsal and lateral surfaces of the neck, trunk and tail (Vickaryous et al., 2004; Carpenter, 2012; Blows, 2015; Arbour \& Currie, 2016). In stegosaurs, the most characteristic feature is the possession of two parasagittal rows of vertical plates and/or spines extending from the neck to the end of the tail (Maidment et al., 2008; Galton, 2012). Together, ankylosaurs and stegosaurs make up a monophyletic group known as Eurypoda (Sereno, 1986). The basal thyreophorans Scutellosaurus, Emausaurus and Scelidosaurus are likely a series of successive outgroups on the line to the Eurypoda clade (Norman et al., 2004; Butler et al., 2008). They had a regular arrangement of dermal armour, which includes several distinct morphologies of osteoderms, such as triangular spines, keeled scutes and small ossicles (Owen, 1863; Colbert, 1981; Haubold, 1990; see below).

The possession of osteoderms is not an exclusive feature of thyreophorans as, for instance, it could be present in other archosauriform clades, i.e. titanosaurian sauropods (D'Emic et al., 2009; Vidal et al., 2014) among dinosaurs, crocodylomorphs and other Late Triassic lineages, such as "rauisuchids", aetosaurs, phytosaurs and several basal forms (Nesbitt, 2011). However, the thyreophorans are the only ones that bear prominent and/or very extensive dermal armour.
Thyreophorans have a long fossil record, which extends from the Lower Jurassic to the Upper Cretaceous. Basal thyreophorans are well documented in the Lower Jurassic of the northern continents, including Europe (Scelidosaurus, Emausaurus), North America (Scutellosaurus) and Asia (see Norman et al., 2004, 2007). Ankylosaurs and stegosaurs are known from the Middle Jurassic to the Cretaceous; ankylosaurs reached the end of the Cretaceous, whereas stegosaurs became apparently extinct sometime during the Late Cretaceous (see Galton, 2012; Pereda Suberbiola et al., 2013; Galton \& Ayyasami, 2017 for a discussion about the possible survival of stegosaurs in India).

In this paper, we describe one isolated osteoderm with thyreophoran affinities from the Bajocian (Humphriesianum Zone) of Ottange-Rumelange, on the Luxembourg-French border. This specimen represents the second Jurassic dinosaur reported from the Grand Duchy of Luxembourg; the only post-Triassic dinosaur remains described so far from Luxembourg were two isolated theropod remains from the marine Hettangian Luxembourg Sandstone Formation (Schlotheimia angulata ammonite Zone) collected at Brouch, near Mersch (Delsate \& Ezcurra, 2014). Other Mesozoic archosaurian records from Luxembourg consist of specimens from the Upper Triassic beds (Hahn et al., 1984; Godefroit et al., 1998).

Institutional abbreviations: MHNL, Luxembourg Natural History Museum, Luxembourg, Grand Duchy of Luxembourg; MNA, Museum of Northern Arizona, Flagstaff, USA; NHMUK, The Natural History Museum, London, U.K. 


\section{Geological background}

The osteoderm MHNL BM766 comes from the RumelangeOttange Quarry of the Grand Duchy of Luxembourg, more precisely from the marls and limestones of the "Marnes sableuses d'Audun-le-Tiche", which are Middle Jurassic in age (Humphriesianum Zone, Lower Bajocian; see Lathuilière, 2005) (Figs 1-2). The stratigraphy of the Mesozoic in Luxembourg and the adjacent areas is exposed in Boulvain et al. (2001), Monari et al. (2001), Belanger et al. (2002), Schintgen \& Förster (2013), Schintgen (2015) and Taverne \& Steurbaut (2017). The "Marnes sableuses d'Audun-leTiche" and the underlying "Calcaires d'Audun-le-Tiche" form the dom 4 on the geological map of Luxembourg (1:25.000; Lucius, 1947).

Hary (1970), Bintz et al. (1973) and, more recently, Lathuilière (2005) and Boulvain et al. (2017) provided a lithostratigraphical log of the Rumelange-Ottange (Cimalux, formerly Intermoselle) Quarry at Rumelange, on the border between the Grand Duchy of Luxembourg and France. The Cimalux Quarry is in the continuation of the disused Weiss Kaul Quarry, and worked by the Groupe Ciments Luxembourgeois. The deposits of the "Marnes sableuses d'Audun-le-Tiche" are dated by the zonal ammonite Stephanoceras humphriesianum (Bintz et al., 1973; Lathuilière, 2005). They correspond to an open sea environment with an oxygenated bottom.

The marls between the reef bodies of the "Calcaires d'Audun-le-Tiche" have provided a rather poor ichthyological fauna, with elasmobranchs (Synechodus, Protospinax, Orectolobiformes) and actinopterygians (cf. Pachycormiformes, Pycnodontiformes).

The alternating limestones and marls overlying the reef bodies (Marnes sableuses d'Audun-le-Tiche; see Fig. 2B) have yielded a more abundant and diverse fauna (Fayard et al., 2005). The marly layer IV/12 covers the shell breccia limestone IV/11 and is more productive in invertebrate fossils (Delsate, 1992, 1997; Delsate \& Felten, 2005, 2015), with actinopterygians (Lepisosteiformes, Pycnodontiformes, probable Pachycormiformes and Furidae), hybodontid sharks (Hybodus sp., Acrodus sp., Polyacrodus sp.), neoselachians (Synechodus levis, Synechodus cf. duffini, Paraorthacodus sp., ?Pseudonotidanus sp., Sphenodus cf. longidens, Paracestracion $s p$., Protospinax magnus and P. bilobatus, Palaeobrachaelurus and indeterminate orectolobiforms). The Holocephali are restricted to a single plate of Callorhinchidae (ploughnose chimaeras). Rare fossil remains of marine reptiles are also present, with the ichthyosaur Ophthalmosaurus sp., indeterminate plesiosaur remains and the crocodile Steneosaurus sp. (Delsate, 2005; Soirfeck, 2005). The deposits have also yielded fossils of foraminifers, poriferans, crustaceans, echinoderms, corals, cephalopods (belemnites, ammonites, nautiloids), gastropods, bivalves, brachiopods, worms, bryozoans, ichnofossils, plants, spores and pollens.

The osteoderm specimen described below was found by one of us (G.F.) and tentatively identified as a myriacanthid palatine plate, but closer examination and comparisons discarded this attribution (Delsate \& Felten, 2015, p. 30). The study of the specimen leads to identify it as an element of the dermal armour of a dinosaur, specifically a thyreophoran. The only dinosaur remains described to date from Luxembourg were an isolated tooth (MHNL BR924) and a pedal phalanx (MHNL BR778) from the Hettangian, both referred to theropods (Delsate \& Ezcurra, 2014).

The occurrence of an isolated osteoderm belonging to a land animal in an open-sea environment suggests that it probably represents a remain dropped from a floating carcass that was transported over a distance from the mainland (for a discussion about the significance of dinosaur remains in marine deposits, see Buffetaut, 1994; Martill et al., 2006).
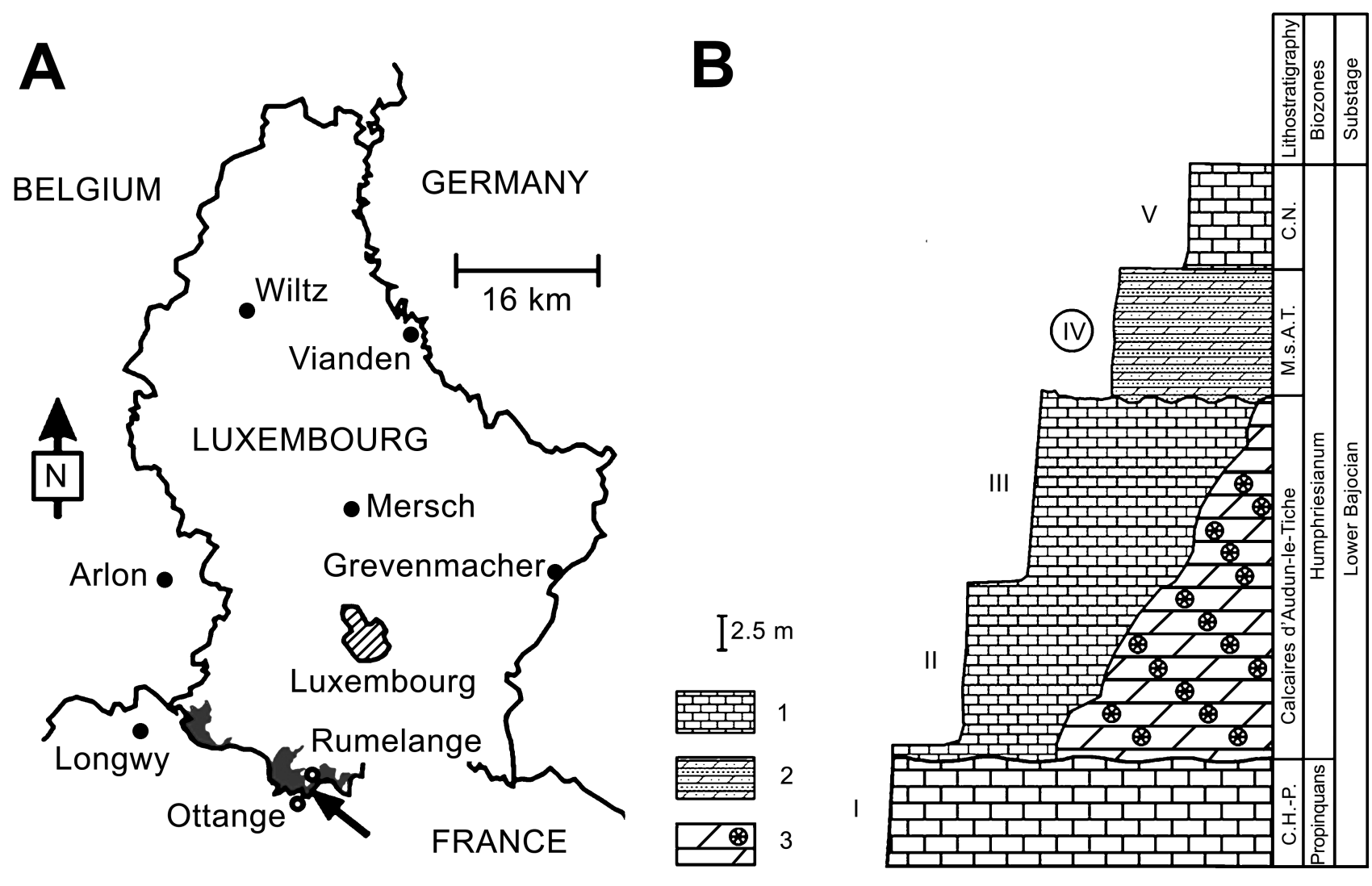

Figure 1. A, map of the Grand Duchy of Luxembourg showing the provenance of the specimen BM766 at the Rumelange-Ottange Cimalux Quarry (indicated by an arrow). The grey fill shows the Middle Jurassic (Dogger) deposits within Grand Duchy of Luxembourg boundary. B, stratigraphic log for the Rumelange-Ottange Cimalux Quarry (following Lathuilière, 2005). Symbols: 1, limestone; 2, marl; 3, bioherm. I-V, quarry levels. Level IV provided the here studied osteoderm MHNL BM766. Abbreviations: C.H-P., Calcaire de Haut-Pont; M.s.A.T., Marnes sableuses d'Audun-le-Tiche; C.N., Calcaire de Nondkeil. 


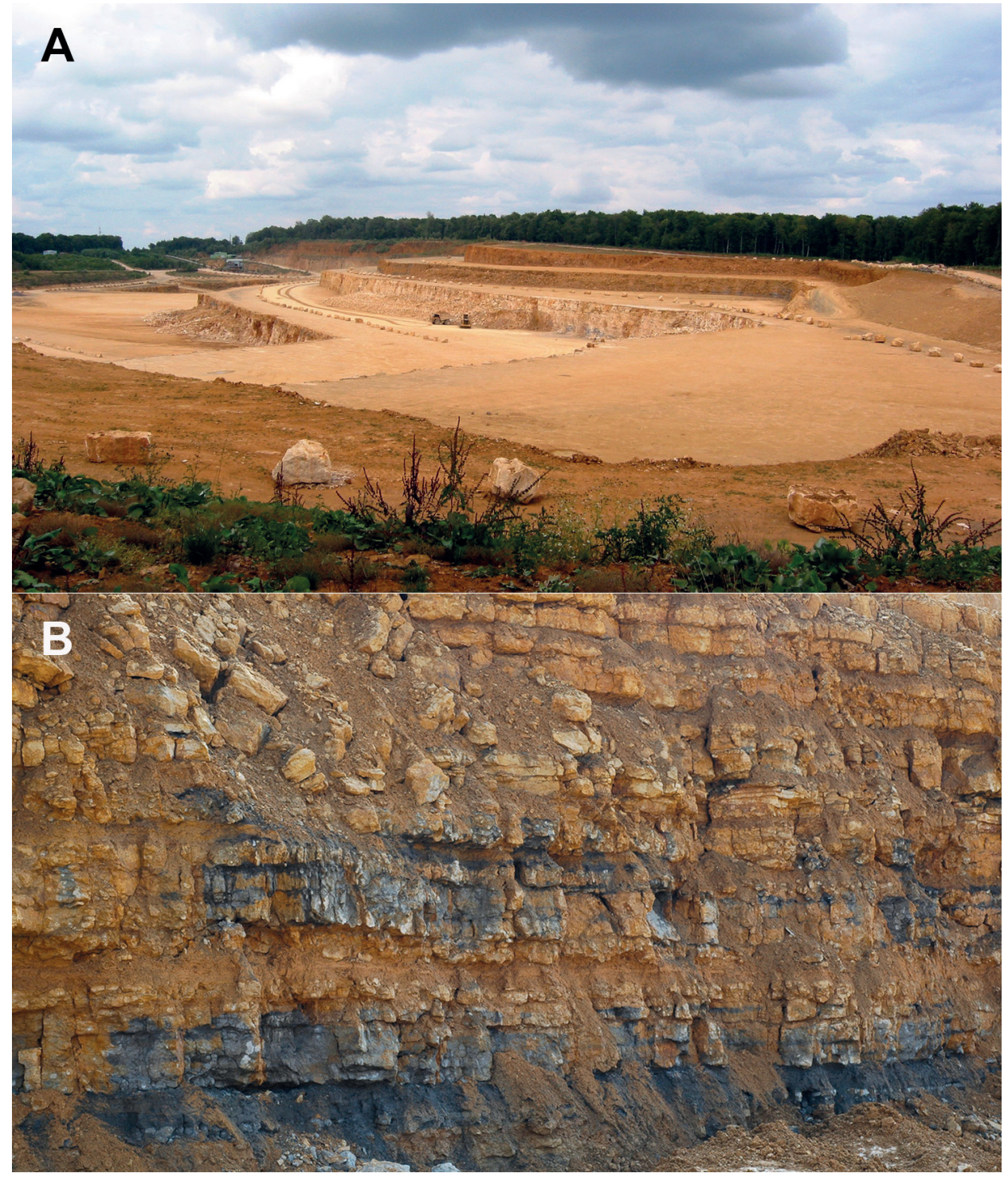

Figure 2. View of the RumelangeOttange Cimalux quarry. A, general view of different quarry levels; B, marly-calcareous deposits of the "Marnes sableuses d'Audun-le-Tiche" (Bajocian).

\section{Description}

The specimen MHNL BM766 (Fig. 3) was found in several pieces that were stuck to reconstruct it. The fossil is grey in colour, with some areas of light brown colour where the surface is covered by a patina formed presumably by iron oxides. A serpulid with a question mark shape is preserved on the ventral surface.

The osteoderm is roughly ellipsoidal in dorsal (external) view and pup-tent shaped (terminology of Ford, 2000; Scheyer $\&$ Sander, 2004) in posterior view (Fig. 3E). The specimen is much longer than high and wide. In lateral/medial view, it has the form of a scalene triangle with three unequal sides, the basal and posterior ones forming an angle slightly higher to $90^{\circ}$ (Figs 3C-D). A sharp keel extends anteroposteriorly along its longest axis; it rises continuously towards the posterodorsal apex, which overhangs the distal border. In dorsal view, the parasagittal keel is asymmetrical and slightly curved (Fig. 3A). The basal side of the osteoderm is excavated, moderately concave (Fig. 3B). The external surface is relatively smooth, finely ornamented with shallow pits and small, irregular grooves. There are no apparent nutrient foramina on the surface.

Some areas of the keel and basal rim are broken; they show a thin cortical bone and an inner region of well-developed cancellous bone (Fig. 3F).

Measurements:

- Maximum basal length: $68 \mathrm{~mm}$.

- Maximum length along the keel: $80 \mathrm{~mm}$.

- Maximum width: $24 \mathrm{~mm}$.

- Maximum height (from base to apex): $29 \mathrm{~mm}$.

\section{Discussion}

\subsection{Identification of the Luxembourg osteoderm}

"Osteoderm" is a broad, generic term for all dermal elements that gives no indication as to the nature of the specimen (Blows, 2001). Osteoderms represent the most commonly documented element of the tetrapod integumentary skeleton (Vickaryous \& Sire, 2009). Thyreophorans possessed several morphotypes of dermal armour (Ford, 2000; Norman et al., 2004). Following the terminology used by Blows (2001), the Luxembourg osteoderm can be identified as a scute. Scutes are defined by this author (see also Ford, 2000) as low ridged, keeled elements of oval shape. The ridge has a rooflike appearance, and the base is generally hollowed. They range from $50 \mathrm{~mm}$ to over $100 \mathrm{~mm}$ long. Dermal scutes were probably placed dorsally in transverse and longitudinal rows along the trunk of the animal. The asymmetrical shape of the Luxembourg scute suggests that it was situated laterally on the body. Based on the general form of the osteoderm and the curvature of the keel (in external view), it is here tentatively interpreted as a scute from the right side.

Blows (2001) notes that the term "scute" was originally used by Owen (1863) to describe dermal armour elements of an articulated specimen of the basal thyreophoran Scelidosaurus harrisonii from the Lower Jurassic of Dorset, UK (NHMUK R1111, paratype). In addition to Scelidosaurus, dermal scutes are also known in the Lower Jurassic basal thyreophoran Scutellosaurus lawleri from Arizona, USA (Colbert, 1981; Rossembaun \& Padian, 2000) and in all members of Ankylosauria (Ford, 2000; Blows, 2001, 


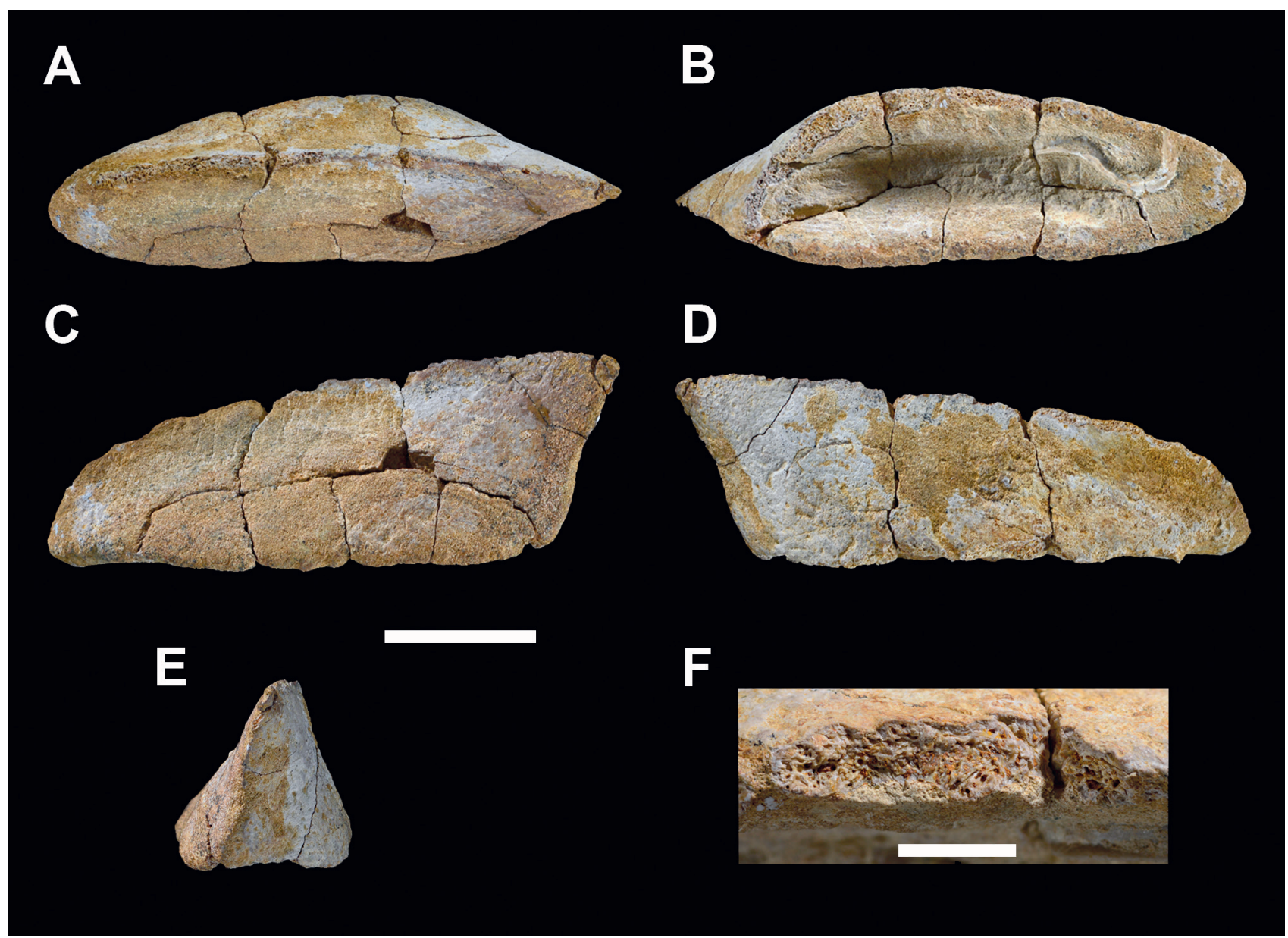

Figure 3. Osteoderm of Thyreophora indeterminate MHNL BM766 in several views: A, dorsal or external; B, ventral or basal; C, lateral (?); D, medial (?); E, posterior. In A and C, the anterior part is on the left; in B and D is on the right. F, loss of surface in the basal border showing the internal structure: a thin cortical layer surrounding a medullary region of trabecular bone. Scale bars: $2 \mathrm{~cm}(\mathrm{~A}-\mathrm{E}), 0.5 \mathrm{~cm}(\mathrm{~F})$.

2015 and references therein). The presence of dermal scutes in the basal thyreophoran Emausaurus ernsti from the Toarcian of Germany is probable but still unconfirmed (Haubold, 1990; Norman et al., 2004). On the contrary, scutes are absent in stegosaurs, whose armour is characterised by the possession of upright dermal plates and/or spines down the midline (Maidment et al., 2008; Galton, 2012).

Colbert (1981) divided the dermal elements of Scutellosaurus into six types (MNA P1.175); among them, the Luxembourg specimen resembles the scutes of the second category, i.e. narrow and long, roof-like scutes, with a keel that forms the apex; these scutes are asymmetrical and the ventral side is deeply concave along a longitudinal axis (Colbert, 1981: fig. 32, II). It was suggested that these scutes were lateral in position, the largest ones perhaps being located in the pelvic region (Colbert, 1981). It should be noted that these scutes are much smaller in size than the one from Luxembourg, as corresponding to a small-bodied thyreophoran (approximately $1 \mathrm{~m}$ long; Maidment et al., 2014).

The dermal armour of Scelidosaurus (3-3.5 m in body length; Maidment et al., 2014) also includes numerous roughly oval scutes that have an outer median longitudinal keel and a hollow base (NHMUK R1111; Owen, 1863; Norman et al., 2004). Some of them, notably a few from the so-called "pelvic block", are similar in both form and size to the Luxembourg osteoderm. However, the Scelidosaurus scutes show a large foramen (sometimes two) on the internal surface that is absent in MHNL BM766, and are more profusely ornamented. Based on articulated skeletons with armour in situ (NHMUK R1111; specimen from the private collection of David Sole, casts on display at the Bristol City Museum and Art Gallery see Carpenter, 2012, fig. 24.13, and at the Charmouth Heritage Coast Centre, Dorset - X.P.S., pers. obs.), Scelidosaurus probably had two longitudinal rows of osteoderms extending from the neck to the sacral region and two additional rows on the dorsolateral side of the body; four longitudinal rows of scutes, including two lateral ones, run down the tail (Norman et al., 2004). The keeled scutes that most resemble to the one from Luxembourg seem to be placed on the pelvic region.

Ankylosaurs have several types of keeled osteoderms on the thoracic and pelvic regions (Ford, 2000). Elongated oval, pup-tent scutes with a posteriorly-pointing peak and a slightly concave base like the one of Luxembourg are known in a number of taxa, mainly in nodosaurids (see Russell, 1940, pl. 8; Ford, 2000, fig. 12; Kirkland et al., 2013, figs 28-30, type D-E armour). However, the external surface of ankylosaurian osteoderms is generally characterized by its rugosity, whereas the smooth, sparse pitting ornamentation observed in the Luxembourg osteoderm looks more like the one of basal thyreophorans (Burns \& Currie, 2014). According to these authors, the relatively smooth osteoderms of basal thyreophorans is the primitive surficial condition (also retained in primitive ankylosaurs). Moreover, the internal structure of the Luxembourg scute is consistent with the one of basal thyreophorans like Scelidosaurus, namely a thin cortical layer covering a network of internal trabecular bone (Scheyer \& Sander, 2004; Main et al., 2005). Among ankylosaurs, nodosaurid and 'polacanthid' osteoderms have a thickened cortex relative to the thinwalled found in ankylosaurids; comparison indicates that the osteoderm histology of ankylosaurs, mainly nodosaurids and ankylosaurids, is highly derived from the basal thyreophoran type (Scheyer \& Sander, 2004). Unlike the basal thyreophorans and stegosaurs, the ankylosaur osteoderms possess extensive structural fibres (Scheyer \& Sander, 2004; Hayashi et al., 2010; Burns \& Currie, 2014). A destructive (histological) analysis is not envisaged for the Luxembourg osteoderm, so this pattern cannot be tested. 
To sum up, the isolated osteoderm from Luxembourg resembles more to those of basal thyreophorans than those of ankylosaurs, but the available evidence is not conclusive for an accurate identification.

Finally, keeled osteoderms have also been described among titanosaurian sauropods, but they are different to those of thyreophorans in several respects, i.e. in having a thicker keel, a marginal ring or 'cingulum' ornamented with tuberosities, and an inner convex (instead of concave or flat) surface (see D'Emic et al., 2009; Zurriaguz et al., 2017 and references). With regard to keeled osteoderms of crocodyliforms, the superficial surface is generally ornamented with large subcircular pitting that is distinct to that of thyreophorans (Ross \& Mayer, 1983; Burns et al., 2013).

\subsection{Middle Jurassic non-stegosaurian thyreophorans}

The fossil record of non-stegosaurian thyreophorans from the Middle Jurassic is rather scarce, but a few occurrences are known in Europe, Africa and India (see Table 1). In England, a large cervical centrum of an indeterminate thyreophoran is known from the Inferior Oolite Group (Aalenian-Bajocian) of Dorset (Galton, 2017). In Scotland, an indeterminate thyreophoran from the Bearreraig Sandstone Formation (either the Rigg Sandstone Member or the Holm Sandstone Member; lower Bajocian) of the Isle of Skye is represented by an incomplete ulna and radius (Clark, 2001). Galton (2017) identified the Skye specimen as Eurypoda indeterminate on the basis of the massiveness of the ulna. Moreover, the ankylosaur Sarcolestes leedsi from the Lower Oxford Clay (middle Callovian) of England is based on a partial mandible with teeth (Lydekker, 1893; Galton, 1983a). Three isolated osteoderms from the Oxford Clay Formation were provisionally referred to Sarcolestes by Galton (1983b, 1994). The dermal elements, regarded as median dorsal scutes from the back, are different from the Luxembourg scute in being thick but lacking a keel or any ventral excavation, and in consisting of mostly compact bone (Galton, 1994). Clark (2001, fig. 5) noted the occurrence of "possible remains of an ankylosaur" in the late Bajocian of England. These remains are presumably two dermal plates from Glourcestershire figured by Reynolds (1939). They come from the Chipping Norton Formation and are really from the lower Bathonian (see Benton \& Spencer, 1995; Weishampel et al., 2004).
Hoffstetter (1957) suggested that the dermal plates may have ankylosaurian affinities, but Galton (1985) and Maidment et al. (2008) identified them as belonging to a stegosaur. Recently, Párraga et al. (2016) pointed out the presence of a possible thyreophoran (ankylosaurian tooth?) in the Bathonian of Oxfordshire, southern England. In Asia, non-stegosaurian thyreophoran records from the Middle Jurassic include the ankylosaur Tianchiasaurus nedegoaperferima Dong, 1993 from the Toutunhe Formation (Callovian; Matzke et al., 2005) of Xinjiang Uyghur Autonomous Region of China, which is regarded as nomen dubium unclassifiable beyond Ankylosauria (Vickaryous et al., 2004; Arbour \& Currie, 2016). In the same region, ankylosaurian remains have also been found in the Middle Jurassic Wucaiwan Formation (Weishampel et al., 2004). In India, a thyreophoran has been reported from the Kota Formation (Andhra Pradesh) and the material, which includes dermal elements, referred to Ankylosauria (Nath et al., 2002). Ayyasami and Yadagiri (cited in Wilson \& Mohabey, 2006) indicated that it represents a crocodylomorph, whereas Norman et al. (2007) considered it as Thyreophora incertae sedis. According to Galton \& Carpenter (2016) [S. Bandyopadhyay, pers. comm. to P.M. Galton and K. Carpenter, 2012], only the jaw bones are referable to a crocodylomorph; the rest of the material is Thyreophora indet. A binomial name has been proposed by Ulansky (2014) for this material; however, this failed to meet the requirements of the ICZN (1999) for purposes of zoological nomenclature, and therefore this name is not valid (see Galton \& Carpenter, 2016). On the other hand, there are conflicting views on the age of the Kota Formation: it has been dated as Lower Jurassic (Hettangian-Pliensbachian) (see Weishampel et al. (2004), but a younger age is more likely (Middle Jurassic to Lower Cretaceous according to Prasad \& Manhas, 2007). In Africa, Ridgwell \& Sereno (2010) reported the discovery of a small-bodied basal thyreophoran from the Tiouarén Formation (probably Middle Jurassic; see Rauhut \& López-Arbarello, 2009) of Niger. The remains, which have not yet been described in detail, include a wide variety of elements from the dermal armour, such as keeled scutes (Ridgwell, 2011). This find and the presence of putative thyreophoran tracks in the Lower Jurassic of northern Africa (Boutakiout et al., 2014 and references) support that thyreophorans may have had an early distribution into the southern continents (see Pereda Suberbiola et al., 2015).

Table 1. Middle Jurassic thyreophoran occurrences (excluding stegosaurs).

\begin{tabular}{|c|c|c|c|c|}
\hline Taxon & Material & Stratigraphic unit & Age & References \\
\hline $\begin{array}{l}\text { Sarcolestes leedsi } \\
\text { (Ankylosauria) }\end{array}$ & $\begin{array}{l}\text { Lower jaw and } \\
\text { osteoderms }\end{array}$ & $\begin{array}{l}\text { Lower Oxford Clay; } \\
\text { Cambridgeshire, England }\end{array}$ & Callovian & $\begin{array}{l}\text { Lydekker (1893), Galton (1983a, } \\
\text { 1983b, 1994) }\end{array}$ \\
\hline $\begin{array}{l}\text { Ankylosauria indet. } \\
\text { ("Tianchiasaurus") }\end{array}$ & Partial skeleton & $\begin{array}{l}\text { Toutunhe Formation; } \\
\text { Xinjiang Uyghur, China }\end{array}$ & Callovian (Matzke et al., 2005) & $\begin{array}{l}\text { Dong (1993), Arbour \& Currie } \\
(2016)\end{array}$ \\
\hline Thyreophora indet. & $\begin{array}{l}\text { Partial skeleton, } \\
\text { including armour }\end{array}$ & Tiouarén Fm.; Niger & $\begin{array}{l}\text { late Middle Jurassic? } \\
\text { (Rauhut \& López-Arbarello, 2009) }\end{array}$ & $\begin{array}{l}\text { Ridgwell \& Sereno (2010), } \\
\text { Ridgwell (2011) }\end{array}$ \\
\hline Thyreophora indet.* & $\begin{array}{l}\text { Partial skeleton, } \\
\text { including armour }\end{array}$ & Kota Fm.; India & $\begin{array}{l}\text { Middle Jurassic-Early Cretaceous? } \\
\text { (Prasad \& Manhas, 2007) }\end{array}$ & Nath et al. (2002) \\
\hline $\begin{array}{l}\text { Thyreophora indet. } \\
\text { (?ankylosaur) }\end{array}$ & Tooth & $\begin{array}{l}\text { Tayton to Forest Marble Fms.; } \\
\text { Oxforshire, England }\end{array}$ & Bathonian & Párraga et al. (2016) \\
\hline $\begin{array}{l}\text { Thyreophora indet. } \\
\text { (Ankylosauria?) }\end{array}$ & Ulna and radius & $\begin{array}{l}\text { Bearreraig Sandstone Fm.; } \\
\text { Isle of Skye, Scotland }\end{array}$ & Lower Bajocian & Clark (2001) \\
\hline Thyreophora indet. & Osteoderm & $\begin{array}{l}\text { Marnes sableuses d'Audun-le-Tiche; } \\
\text { Luxembourg }\end{array}$ & Lower Bajocian & This work \\
\hline Thyreophora indet. & Cervical centrum & $\begin{array}{l}\text { Inferior Oolite Group; } \\
\text { Dorset, England }\end{array}$ & Aalenian-Bajocian & Galton (2017) \\
\hline
\end{tabular}

*Note: jaw material described as an ankylosaur by Nath et al. (2002) is now regarded as crocodylomorph (see Galton and Carpenter, 2016). 


\section{Conclusions}

An isolated osteoderm (MHNL BM766) has been found in the marls and limestones of the "Marnes sableuses d'Audunle-Tiche" in the Ottange-Rumelange Quarry of Luxembourg, of Middle Jurassic (Lower Bajocian) age, in association to fossils of a diverse marine fauna, including invertebrates and vertebrates. The osteoderm is identified as a keeled scute belonging to a thyreophoran dinosaur, presumably to a basal thyreophoran (but a referral to an early ankylosaur cannot be definitively excluded). This find represents the second Jurassic dinosaur fossil specimen reported from the Grand Duchy of Luxembourg. Moreover, it is the only one described from the Middle Jurassic of Luxembourg and one of the few thyreophoran occurrences from formations of this age in Europe and worldwide.

\section{Acknowledgments}

We thank Evgeny Popov (Saratov) and Alexander Averianov (Moscow) for useful discussions about the specimen, and Roby Weis, Ben Thuy and Alain Faber (MNHN, Luxembourg), Frédéric Boulvain (Univ. Liège) and Bernard Lathuilière (Univ. Lorraine) for discussions about the stratigraphy and fauna, and for technical support. For access to material and assistance with specimens under her care, especially the dermal armour of Scelidosaurus, we are grateful to Sandra Chapman (NHMUK, London). We also thank the reviewers Peter M. Galton (Univ. Bridgeport) and Pascal Godefroit (IRSNB, Brussels) for their constructive comments on this manuscript, and Annick Anceau for her editorial help. Lilian Cazes (MNHN, Paris) kindly provided the photographs of the osteoderm. We are also very grateful to Nathalie Bardet (CNRS-MNHN, Paris) for her help with the photographs, and to Mikel Arlegi and Asier Gómez-Olivencia (UPV/EHU, Bilbao) for their help in the 3-D scanning of the osteoderm. Research work of XPS was supported by the Gobierno Vasco/Eusko Jaurlaritza (research group IT-1044-16) and the Universidad del País Vasco (UPV/EHU, research group PPG17/05). DD thanks Vanessa Limpach (HENALLUX, Bastogne) for her continuous support.

\section{References}

Arbour, V.M. \& Currie, P.J., 2016. Systematics, phylogeny and palaeobiogeography of the ankylosaurid dinosaurs. Journal of Systematic Palaeontology, 14/5, 385-444. https://doi.org/10.1080 /14772019.2015.1059985

Belanger, I., Delsate, D., Ghysel, P., Laloux, M. \& Boulvain, F., 2002. Carte géologique de Wallonie : Saint-Léger - Messancy 71/3-4, Musson - Le Fays 71/7-8, Houwald 72/1. 1/25.000. Namur, Ministère de la Région wallonne, Direction générale des ressources naturelles et de l'environnement, avec une notice explicative de $35 \mathrm{p}$.

Benton, M.J. \& Spencer, P.S., 1995. Fossil Reptiles of Great Britain. Chapman and Hall, London, Geological Conservation Review Series, 10, 386 p. https://doi.org/10.1007/978-94-011-0519-4

Bintz, J., Hary, A. \& Muller, A., 1973. Luxembourg. In Waterlot G., Beugnies, A. \& Bintz, J., Ardenne - Luxembourg. Masson, Paris, Guides géologiques régionaux, 135-188.

Blows, W.T., 2001. Dermal armor of the polacanthine dinosaurs. In Carpenter, K. (ed.), The Armored Dinosaurs. Indiana University Press, Bloomington, 363-385.

Blows, W.T., 2015. British polacanthid dinosaurs. Siri Scientific Press, Manchester, UK, Monograph Series volume 7, $224 \mathrm{p}$.

Boulvain, F., Belanger, I., Delsate, D., Ghysel, P., Godefroit, P., Laloux, M., Monteyne, R. \& Roche, M., 2001. Triassic and Jurassic lithostratigraphic units (Belgian Lorraine). In Bultynck, P. \& Dejonghe, L. (eds), Lithostratigraphic scale of Belgium. Geologica Belgica, 4/1-2, 113-119.

Boulvain, F., Belanger, I., Colbach, R., Dechamps, S., Delsate, D., Deligny, D., Ghysel, P., Michel, J., Philippo, S. \& Ramlot, B., 2017. New sedimentological data from Triassic to Jurassic boreholes (Bonnert, Haebicht, Grouft, Grund, Consdorf) and sections (Tontelange, Differdange, Rumelange) from Southern Belgium and Luxembourg. Geological Survey of Belgium, Professional Papers 319, $43 \mathrm{p}$.
Boutakiout, M., Masrour, M. \& Pérez-Lorente, F., 2014. Icnitas tireóforas y terópodas en Ansous (Pliensbachiense, Alto Atlas Central, Marruecos). Geogaceta, 55, 75-78.

Buffetaut, E., 1994. The significance of dinosaur remains in marine sediments: An investigation based on the French record. Berliner Geowissenschaftliche Abhandlungen Reihe E, 13, 125-133.

Burns, M.E. \& Currie, P.J., 2014. External and internal structure of ankylosaur (Dinosauria, Ornithischia) osteoderms and their systematic relevance. Journal of Vertebrate Paleontology, 34/4, 835-851. https://doi.org/10.1080/02724634.2014.840309

Burns, M.E., Vickaryous, M.K. \& Currie, P.J., 2013. Histological variability in fossil and recent alligatoroid osteoderms: Systematic and functional implications. Journal of Morphology, 274, 676686. https://doi.org/10.1002/jmor.20125

Butler, R.J., Upchurch, P. \& Norman, D.B., 2008. The phylogeny of the ornithischian dinosaurs. Journal of Systematic Palaeontolology, 6, 1-40. https://doi.org/10.1017/S1477201907002271

Carpenter, K., 2012. Ankylosaurs. In Brett-Surman, M.K., Holtz, T.R., Jr. \& Farlow, J.O. (eds), The Complete Dinosaur, 2nd ed. Indiana University Press, Bloomington, 505-525.

Clark, N.D.L., 2001. A thyreophoran dinosaur from the Early Bajocian (Middle Jurassic) of the Isle of Skye, Scotland. Scottish Journal of Geology, 37/1, 19-26. https://doi.org/10.1144/ sjg37010019

Colbert, E.H., 1981. A primitive ornithischian dinosaur from the Kayenta Formation of Arizona. Bulletin of the Museum of Northern Arizona, 53, 1-61.

D'Emic, M.D., Wilson, J.A. \& Chatterjee, S., 2009. The titanosaur (Dinosauria: Sauropoda) osteoderm record: review and first definitive specimen from India. Journal of Vertebrate Paleontology, 29/1, 165-177. https://doi.org/10.1671/039.029.0131

Delsate, D., 1992. Chondrichthyens mésozoïques du Luxembourg. Note préliminaire. Bulletin de la Société des Naturalistes luxembourgeois, 93, 181-193.

Delsate, D., 1997. Chondrichthyens mésozoïques du Luxembourg. Compléments. In Maubeuge, P.L. \& Delsate, D. (eds), Notes paléontologiques et biostratigraphiques sur le Grand-Duché de Luxembourg et les régions voisines. Travaux scientifiques du Musée d'Histoire naturelle de Luxembourg, 27, 53-79.

Delsate, D., 2005. Les reptiles marins. In Fayard, J.P., Gross, N., Lajournade, J.B., Lathuillière, B., Vailly, G. \& Weis, R. (eds). Fossiles et minéraux de la carrière d'Ottange-Rumelange. Geolor \& AGMP, Thionville (France) \& Bous (Grand-Duché de Luxembourg), 117-122.

Delsate, D. \& Ezcurra, M., 2014. The first Early Jurassic (late Hettangian) theropod dinosaur remains from the Grand Duchy of Luxembourg. Geologica Belgica, 17/2, 175-181.

Delsate, D. \& Felten, R., 2005. Les poissons. In Fayard, J.P., Gross, N., Lajournade, J.B., Lathuillière, B., Vailly, G. \& Weis, R. (eds). Fossiles et minéraux de la carrière d'Ottange-Rumelange. Geolor \& AGMP, Thionville (France) \& Bous (Grand-Duché de Luxembourg), 101-116.

Delsate D. \& R. Felten, R., 2015. Chondrichthyens et Actinoptérygiens du Bajocien inférieur du Grand-Duché de Luxembourg et des régions frontalières. Ferrantia, 71, 9-38.

Dong, Z., 1993. An ankylosaur (ornithischian dinosaur) from the Middle Jurassic of the Junggar Basin, China. Vertebrata PalAsiatica, 31, 257-266.

Fayard, J.-P., Gross, N., Lajournade, J.-B., Lathuilière, B., Vailly, G. \& Weis, R., 2005. Fossiles et minéraux de la carrière d'OttangeRumelange. Geolor \& AGMP, Thionville (France) \& Bous (Grand-Duché de Luxembourg), $152 \mathrm{p}$.

Ford, T.L., 2000. A review of ankylosaur osteoderms from New Mexico and a preliminary review of ankylosaur armor. In Lucas, S.G. \& Heckert, A.B. (eds), Dinosaurs of New Mexico. New Mexico Museum of Natural History Science Bulletin, 17, 157176.

Galton, P.M., 1983a. Sarcolestes leedsi Lydekker, an ankylosaurian dinosaur from the Middle Jurassic of England. Neues Jarhbuch für Geologie und Paläontologie, Monatshefte, 1983/3, 141-155.

Galton, P.M., 1983b. Armored dinosaurs (Ornithischia: Ankylosauria) from the Middle and Upper Jurassic of Europe. Palaeontographica A, 182/1-3, 1-23.

Galton, P.M., 1985. British plated dinosaurs (Ornithischia, Stegosauridae). Journal of Vertebrate Paleontology, 5, 211-254. https://doi.org/10.1080/02724634.1985.10011859

Galton, P.M., 1994. Dermal scutes of Sarcolestes, an ankylosaurian dinosaur from the Middle Jurassic of England. Neues Jahrbuch für Geologie und Paläontologie, Monatshefte, 1994/12, 726-732.

Galton, P.M., 2012. Stegosaurs. In Brett-Surman, M.K., Holtz, T.R., Jr. \& Farlow, J.O. (eds), The Complete Dinosaur, 2nd ed. Indiana University Press, Bloomington, 482-504. 
Galton, P.M., 2017. Purported earliest bones of a plated dinosaur (Ornithischia: Stegosauria): a "dermal tail spine" and a centrum from the Aalenian-Bajocian (Middle Jurassic) of England, with comments on other early thyreophorans. Neues Jahrbuch für Geologie und Paläontologie, Abhandlungen, 285/1, 1-10.

Galton, P.M. \& Ayyasami, K., 2017. Purported latest bone of a plated dinosaur (Ornithischia: Stegosauria), a "dermal plate" from the Maastrichtian (Upper Cretaceous) of southern India. Neues Jahrbuch für Geologie und Paläontologie, Abhandlungen, 285/1, 91-96. https://doi.org/10.1127/njgpa/2017/0671

Galton, P.M. \& Carpenter, K., 2016. The plated dinosaur Stegosaurus longispinus Gilmore, 1914 (Dinosauria: Ornithischia; Upper Jurassic, western USA), type species of Alcovasaurus n. gen. Neues Jahrbuch für Geologie und Paläontologie, Abhandlungen, 279/2, 185-208. https://doi.org/10.1127/njgpa/2016/0551

Godefroit, P., Cuny, G., Delsate, D. \& Roche, M., 1998. Late Triassic vertebrates from Syren (Luxembourg). Neues Jahrbuch für Geologie und Paläontologie, Abhandlungen, 210, 305-343.

Hahn, G., Lepage, J. C. \& Wouters, G., 1984. Cynodontier-Zähne aus der Ober-Trias von Medernach, Grossherzogtum, Luxembourg. Bulletin de la Société Belge de Géologie, de Paléontologie et d'Hydrologie, 93, 357-373.

Hary, A., 1970. Récifs de coraux du Bajocien moyen aux environs de Rumelange. Archives de l'Institut Grand-Ducal de Luxembourg, Section Sciences naturelles, physiques et mathématiques, N.S., 34, 431-455.

Haubold, H., 1990. Ein neuer Dinosaurier(Ornithischia, Thyreophora) aus dem unteren Jura des Nördlichen Mitteleuropa. Revue de Paléobiologie, 9, 149-177.

Hayashi, S., Carpenter, K., Scheyer, T.M., Watabe, M. \& Suzuki, D., 2010. Function and evolution of ankylosaur dermal armor. Acta Palaeontologica Polonica, 55/2, 213-228. http://doi.org/10.4202/ app. 2009.0103

Hoffstetter, R., 1957. Quelques observations sur les Stégosaurinés. Bulletin du Muséum National d'Histoire Naturelle, Paris, 29/6, 537-547.

ICZN, 1999. International Code of Zoological Nomenclature, 4th ed. International Trust for Zoological Nomenclature, London, 306 p.

Kirkland, J.I, Alcalá, L., Loewen, M.A., Espílez, E., Mampel, L. \& Wiersma, J.P., 2013. The basal nodosaurid ankylosaur Europelta carbonensis n. gen., n. sp. from the Lower Cretaceous (Lower Albian) Escucha Formation of Northeastern Spain. PLoS ONE, 8/12, e80405. https://doi.org/10.1371/journal.pone.0080405

Lathuilière, B., 2005. Introduction géologique à la carrière d'OttangeRumelange. In Fayard, J.-P., Gross, N., Lajournade, J.-B., Lathuilière, B., Vailly, G. \& Weis, R. (eds), Fossiles et minéraux de la carrière d'Ottange-Rumelange. Geolor \& AGMP, Thionville (France) \& Bous (Grand-Duché de Luxembourg), 15-26.

Lucius, M., 1947. Carte géologique du Luxembourg : Feuille n¹, Esch-sur-Alzette. 1/25 000. Luxembourg, Service géologique du Luxembourg.

Lydekker, R., 1893. On the jaw of a new carnivorous dinosaur from the Oxford Clay of Peterborough. Quarterly Journal of the Geological Society of London, 49, 284-287. https://doi org/10.1144/GSL.JGS.1893.049.01-04.46

Maidment, S.C.R., Norman, D.B., Barrett, P.M. \& Upchurch, P., 2008. Systematics and phylogeny of Stegosauria (Dinosauria: Ornithischia). Journal of Systematic Palaeontology, 6, 367-407. https://doi.org/10.1017/S1477201908002459

Maidment, S.C.R., Henderson, D.M. \& Barrett, P.M., 2014. What drove reversions to quadrupedality in ornithischian dinosaurs? Testing hypotheses using centre of mass modelling. Naturwissenschaften, 101, 989-1001. https://doi.org/10.1007/s00114-014-1239-2

Main, R.P., Ricqlès, A. de, Horner, J.R. \& Padian, K., 2005. The evolution and function of thyreophoran dinosaur scutes: implications for plate function in stegosaurs. Paleobiology, 31/2, 291-314. https://doi.org/10.1666/0094-8373(2005)031[0291:TEA FOT]2.0.CO;2

Martill, D.M., Earland, S. \& Naish, D., 2006. Dinosaurs in marine strata: evidence from the British Jurassic, including a review of the allochthonous vertebrate assemblage from the marine Kimmeridge Clay Formation (Upper Jurassic) of Great Britain. In Colectivo Arqueológico-Paleontológico Salense (ed.), Actas de las III Jornadas sobre Dinosaurios y su Entorno. Salas de los Infantes, Burgos, 35-72.

Matzke, A.T., Maisch, M.W., Sun, G., Pfretzschner, H.-U. \& Stöhr, H. 2005. A new Middle Jurassic xinjiangchelyid turtle (Testudines; Eucryptodira) from China (Xinjiang, Junggar Basin). Journal of Vertebrate Paleontology, 25, 63-70. https://doi.org/10.1671/02724634(2005)025[0063:ANMJXT]2.0.CO;2
Monari, S., Valentini, M. \& Conti, M.A., 2011. Earliest Jurassic patellogastropod, vetigastropod, and neritimorph gastropods from Luxembourg with considerations on the Triassic-Jurassic faunal turnover. Acta Palaeontologica Polonica, 56/2, 349-384. http://dx.doi.org/10.4202/app.2010.0098

Nath, T.T., Yadagiri, P. \& Moitra, A.K., 2002. First record of armoured dinosaur from the Lower Jurassic Kota Formation, Prahita-Godivari Valley, Andhra Pradesh. Journal of the Geological Society of India, 59, 575-577.

Nesbitt, S.J., 2011. The early evolution of archosaurs: relationships and the origin of major clades. Bulletin of the American Museum of Natural History, 352, 1-292.

Norman, D.B., Witmer, L.M. \& Weishampel, D.B., 2004. Basal Thyreophora. In Weishampel, D.B., Dodson, P. \& Osmólska, H. (eds), The Dinosauria, 2nd ed. University of California Press, Berkeley, 335-342.

Norman, D.B., Butler, R.J. \& Maidment, S.C.R. 2007. Reconsidering the status and affinities of the ornithischian dinosaur Tatisaurus oehleri Simmons, 1965. Zoological Journal of the Linnean Society, 150, 865-874. https://doi.org/10.1111/j.1096-3642.2007.00301.x

Owen, R., 1863. A monograph of the Fossil Reptilia of the Liassic formations. Part II. A monograph of a fossil dinosaur (Scelidosaurus harrisonii Owen) of the Lower Lias. Monograph of the Palaeontographical Society, 2, 1-26.

Párraga, J., Bernard, E., Brewer, P., Ward, D.J. \& Wills, S. 2016. A diverse new Late Bathonian microvertebrate assemblage from Woodeaton Quarry, Oxfordshire, UK. Abstracts of Papers, 76th Annual Meeting of the Society of Vertebrate Paleontology, Salt Lake City, UT, 22.

Pereda-Suberbiola, X., Galton, P.M., Mallison, H. \& Novas, F., 2013. A plated dinosaur (Ornithischia, Stegosauria) from the Early Cretaceous of Argentina, South America: an evaluation. Alcheringa, 37, 65-78. https://doi.org/10.1080/03115518.2012.70 2531

Pereda-Suberbiola, X., Díaz-Martínez, I., Salgado, L. \& De Valais, S., 2015. Síntesis del registro fósil de dinosaurios tireóforos en Gondwana. In Fernández, M. \& Herrera, Y. (eds), Reptiles Extintos - Volumen en Homenaje a Zulma Gasparini. Publicación Electrónica de la Asociación Paleontológica Argentina, 15/1, 90-107.

Prasad, G.V.R. \& Manhas, B.K., 2007. A new docodont mammal from the Jurassic Kota Formation of India. Palaeontologia Electronica, 10/2, 7A, 11 p.

Rauhut, O.W.M. \& López-Arbarello, A., 2009. Considerations on the age of the Tiouarén Formation (Iullemmeden Basin, Niger, Africa) Implications for Gondwanan Mesozoic terrestrial vertebrate faunas. Palaeogeography, Palaeoclimatology, Palaeoecology, 271, 259-267. https://doi.org/10.1016/j.palaeo.2008.10.019

Reynolds, S.H. (1939). On a collection of reptilian bones from the Oolite of Stow-on-the-Wold, Gloucestershire. Geological Magazine, 76/5, 193-214. https://doi.org/10.1017/S0016756800070990

Ridgwell, N., 2011. A basal thyreophoran (Dinosauria, Ornithischia) from Africa clarifies the early evolution of armored dinosaurs Program and Abstracts, 71st Annual Meeting of the Society of Vertebrate Paleontology, Las Vegas, NV. Journal of Vertebrate Paleontology 31, Supplement 2, 179.

Ridgwell, N. \& Sereno, P.C., 2010. A basal thyreophoran (Dinosauria, Ornithischia) from the Tiouraren Formation of Niger. Program and Abstracts, 70th Anniversary Meeting of the Society of Vertebrate Paleontology, Pittsburgh, PA. Journal of Vertebrate Paleontology 30, Supplement 2, 150A-151A.

Ross, F.D. \& Mayer, G.C., 1983. On the dorsal armor of the Crocodilia. In Rhodin, A.G.J. \& Miyata, K. (eds), Advances in Herpetology and Evolutionary Biology: Essays in Honor of Ernest E. Williams. Museum of Comparative Zoology, Cambridge, Massachusetts, 305-331.

Rossembaun, J.N. \& Padian, K., 2000. New material of the basal thyreophoran Scutellosaurus lawleri from the Kayenta Formation (Lower Jurassic) of Arizona. PaleoBios, 20/1, 13-23.

Russell, L.S., 1940. Edmontonia rugosidens (Gilmore), an armored dinosaur from the Belly River series of Alberta. University of Toronto Studies, Geological Series, 43, 1-15.

Scheyer, T.M. \& Sander, P.M., 2004. Histology of ankylosaur osteoderms: implications for systematics and function. Journal of Vertebrate Paleontology, 24/4, 874-893. https://doi. org/10.1671/0272-4634(2004)024[0874:HOAOIF]2.0.CO;2

Schintgen, T., 2015. Exploration for deep geothermal reservoirs in Luxembourg and the surroundings - perspectives of geothermal energy use. Geothermal Energy, 3/9, 30 p. https://doi.org/10.1186/ s40517-015-0028-2 
Schintgen, T. \& Förster, A., 2013. Geology and basin structure of the Trier-Luxembourg Basin - Implications for the existence of a buried Rotliegend graben. Zeitschrift der Deutschen Gesellschaft für Geowissenschaften, 164/4, 615-637. https://doi. org/10.1127/1860-1804/2013/0025

Sereno, P.C., 1986. Phylogeny of the bird-hipped dinosaurs (order Ornithischia). National Geographic Research, 2, 234-256.

Sereno, P.C., 1998. A rationale for phylogenetic definitions, with application to the higher-level taxonomy of Dinosauria. Neues Jahrbuch für Geologie und Paläontologie, Abhandlungen, 210/1, 41-83.

Sereno, P.C., 1999. The evolution of the dinosaurs. Science, 284, 2137-2147. https://doi.org/10.1126/science.284.5423.2137

Soirfeck, E., 2005. L'ichthyosaure d'Ottange-Rumelange. In Fayard, J.P., Gross, N., Lajournade, J.B., Lathuillière, B., Vailly, G. \& Weis, R. (eds). Fossiles et minéraux de la carrière d'Ottange-Rumelange. Geolor \& AGMP, Thionville (France) \& Bous (Grand-Duché de Luxembourg), 123-126.

Taverne, L. \& Steurbaut, E., 2017. Osteology and relationships of Luxembourgichthys ("Pholidophorus") friedeni gen. nov. (Teleostei, "Pholidophoriformes") from the Lower Jurassic of Belgium and the Grand Duchy of Luxembourg. Geologica Belgica, 20/1-2, 53-67. http://dx.doi.org/10.20341/gb.2017.003

Ulansky, R.E., 2014. Dinosaur classification. Basal Thyreophora \& Stegosauria. Dinologia, 8 p.

Vickaryous, M.K. \& Sire, J.-Y., 2009. The integumentary skeleton of tetrapods: origin, evolution, and development. Journal of Anatomy, 214, 407-644. https://doi.org/10.1111/j.14697580.2008.01043.x

Vickaryous, M.K., Maryańska, T. \& Weishampel, D.B., 2004. Ankylosauria. In Weishampel, D.B., Dodson, P. \& Osmólska, H. (eds), The Dinosauria, 2nd ed. University of California Press, Berkeley, 363-392.

Vidal, D., Ortega, F. \& Sanz, J.L., 2014. Titanosaur osteoderms from the Upper Cretaceous of Lo Hueco (Spain) and their implications on the armor of Laurasian titanosaurs. PLoS ONE, 9/8, e102488. https://doi.org/10.1371/journal.pone.0102488

Weishampel, D.B., Barrett, P.M., Coria, R.A., Le Loeuff, J., Xu, X., Zhao, X., Sahni A., Gomani, E.M.P. \& Noto, C.R., 2004. Dinosaur distribution. In Weishampel, D.B., Dodson, P. \& Osmólska, H. (eds), The Dinosauria, 2nd ed. University of California Press, Berkeley, 517-606.

Wilson, J.A. \& Mohabey, D.M., 2006. A Titanosauriform (Dinosauria: Sauropoda) axis from the Lameta Formation (Upper Cretaceous: Maastrichtian) of Nand, Central India. Journal of Vertebrate Palaeontology, 26, 471-479. https://doi.org/10.1671/02724634(2006)26[471:ATDSAF]2.0.CO;2

Zurriaguz, V., Martinelli, A., Rougier, G.W. \& Ezcurra, M.D., 2017. A saltasaurine titanosaur (Sauropoda: Titanosauriformes) from the Angostura Colorada Formation (upper Campanian, Cretaceous) of northwestern Patagonia, Argentina. Cretaceous Research, 75, 101-114. https://doi.org/10.1016/j.cretres.2017.03.016

Manuscript received 28.08.2017, accepted in revised form 15.01.2018, available on line 13.03.2018.

A 3D image of the osteoderm MHNL BM766 in ply file format is available online as supplementary material (see https://doi.org/10.20341/gb.2018.001). 